\title{
Jurnal
}

Manajomen Polayanan Publik

Administration Of E-Invoicing Value Added Tax (Comparative Study between Indonesia and Australia)

Supply Chain Integration (SCI) Fashion Products Made By SMEs In Response To Improve Performance Development Of Tourism In West Java

Analysis on Fees Exemption Policy of Land and Building Rights Acquisition in Jakarta

Analysis of Tax Authority Readiness in Tax Policy on Digital Economy

Implementation of Large Scale Social Restrictions Policy (PSBB) in Bogor District Government

Critical Success Factors In Implementing Employee Information System Based On E-Government In The Bureau Of Public Affairs At The Regional Secretariat Of West Java Province

Implementation of Billboard Tax Policy in the City of Bandung

Public-Private Partnership In Water Supply Of DKI Jakarta 


\section{Supply Chain Integration (SCI) Fashion Products Made By SMEs In Response to Improve Performance Development Of Tourism In West Java}

\begin{abstract}
ABSTRAK
Perkembangan pariwisata di Jawa Barat dapat menjadi kesempatan bagi UMKM di Kota Bandung untuk memenuhi kebutuhan wisatawan dan memberikan dampak peningkatan pendapatan bagi UMKM. Sebagai respon dari perkembangan pariwisata diperlukan solusi dan cara yang tepat bagi UMKM untuk menjawab tantangan tersebut. Kerjasama dalam pengelolaan rantai pasokan (supply chain) diasumsikan menjadi sebuah kegiatan yang tepat untuk meningkatkan kinerja organisasi dan meningkatkan keunggulan kompetitif. Supply Chain Integration (SCI) dapat mempengaruhi kinerja organisasi. Artikel ini mempelajari dampak dari prosedur Supply Chain Integration terhadap kinerja organisasi dan mengeksplorasi efek SCI pada kinerja organisasi di Usaha Mikro, Kecil dan Menengah (UMKM) pada produk fashion di Jawa Barat. Artikel ini menggunakan kuesioner yang dikembangkan dengan skala pengukuran yang divalidasi dari studi sebelumnya dan data empiris dikumpulkan melalui kuesioner survei dari 207 UMKM dengan menggunakan probability sampling. Penelitian ini adalah penelitian kuantitatif dengan analisis menggunakan SEM-PLS. Penelitian ini memberikan sebuah rekomendasi bagi UMKM di Jawa Barat pada khususnya.
\end{abstract}

Kata Kunci: MSME; Integrasi rantai pasokan; kinerja perusahaan

\section{ABSTRACT}

The advancement of the travel industry in West Java can be an open door for MSMEs in the city of Bandung to address the issues of sightseers and affect expanding pay for MSMEs. In light of the advancement of the travel industry required arrangements and fitting ways for SMEs to answer these difficulties. Collaboration in gracefully bind the executives is thought to be a fitting action to improve hierarchical execution and increment upper hand. Gracefully Chain Incorporation (SCl) can influence authoritative execution. This article considers the effect of Gracefully Chain Mix systems on authoritative execution and investigates the impact of $\mathrm{SCl}$ on hierarchical execution in Miniaturized scale, Little and Medium Undertakings (MSMEs) on design items in West Java. This article utilizes a poll that was created with an approved estimation scale from past investigations and exact information was gathered through a study survey from 207 MSMEs utilizing likelihood testing. This exploration is a quantitative report with investigation utilizing SEM-PLS. This examination gives a suggestion to MSMEs in West Java specifically.

Keyword: MSME; Supply Chain Integration; firm performance

\section{ARTICLE HISTORY}

Submited : 31/12/2019

Accepted : $13 / 06 / 2020$

Published : 28/08/2020

KATA KUNCI

MSME; Integrasi rantai pasokan; kinerja perusahaan

\section{KEYWORDS} MSME; Supply Chain Integration; firm performance 


\section{INTRODUCTION}

The tourism industry is increasingly growing and developing so as to make more and more tourist destinations in various regions grow. The fashion product industry is one of the industries that is related and influences the social and economic life of the community, and also increases the country's foreign exchange and creates employment. Indonesia is a country that has a very diverse tourism potential, the types of tourism found in Indonesia are also diverse and have their own uniqueness, including nature tourism, cultural tourism, culinary tourism, shopping tourism, and creative tourism. Indonesia's natural tourism can compete internationally because Indonesia's natural beauty is very rich and can be said to not be owned by other countries, in fact there are still many regions in Indonesia that have not become tourist destinations but have enormous potential to become tourism destinations.

Table 1. Number of tourists coming to Indonesia

\begin{tabular}{|c|c|}
\hline Year & Number of tourists / people \\
\hline 2017 & 14.039 .799 \\
\hline 2018 & 15.810 .305 \\
\hline
\end{tabular}

Source: Badan Pusat Statistik (2013)

Based on data from the Central Statistics Agency, the number of foreign tourist arrivals to Indonesia increased by 26.6\%, which was originally around 14,039,799 in 2017, increasing to 15,810,305 people in 2018 the number is dominated by tourists from Malaysia (Badan Pusat Statistik, 2013).

The growth and development of this tour can be an opportunity for tourist recipient communities in this case SMEs in West Java in providing tourism support facilities for tourists. The large number of tourist visits is a demand for MSMEs in Bandung to be able to meet the needs of tourists and this also has an impact on increasing MSME income and stimulates the community to create new MSMEs as an alternative to be able to meet the needs of tourists who continue to increase. Prasetyo \& Suryoko, (2018) argued that the development of tourism can lead to an increase in tourist visits, it can have a positive impact on MSMEs around the tourist area. UMKM can be a vehicle for tourism that can develop along with the process of tourism development itself.

MSMEs have a significant job in molding systems for monetary improvement in a nation. In Indonesia, particularly in West Java, the improvement of MSMEs in the change period has gotten a lot of consideration from the administration. MSMEs have a significant job in forming procedures for monetary improvement in a nation. In Indonesia, particularly in West Java, the improvement of MSMEs in the change time has gotten a lot of consideration from the administration. Unique regard for creating MSMEs additionally affects the quantity of MSMEs every year. The accompanying information from the Biro Pusat Stastistik in regards to the improvement of the quantity of MSMEs in Indonesia: 
Table 2. The development of the number of MSMEs in West Java

\begin{tabular}{|c|c|}
\hline Year & Jumlah UMKM \\
\hline 2008 & 51.409 .612 \\
\hline 2009 & 52.764 .603 \\
\hline 2010 & 53.823 .732 \\
\hline 2011 & 55.206 .444 \\
\hline 2012 & 56.534 .592 \\
\hline 2013 & 57.895 .721 \\
\hline
\end{tabular}

Source: Badan Pusat Statistik (2015)

From the information over, the quantity of MSMEs every year has an ever-expanding pattern, as a reaction to the advancement of the travel industry, the correct procedure is required for MSMEs to answer the difficulties and openings that come. The methodology is a driver that coordinates the exercises of MSMEs in situating their organizations and items or administrations in rivalry with an end goal to improve organization execution. MSMEs in keeping up their essence amidst serious business rivalry will pick and actualize procedures that are suitable to the character and ecological states of the organization. The correct choice in picking a technique will have the option to outflank its rivals in development and productivity and look after manageability. One of the endeavors completed is to deal with the gracefully chain well and incorporated. Shoppers need merchandise and ventures that are proper at a sensible cost and in a sensible time with high caliber at the correct spot. On the off chance that MSMEs need to contend in new markets, their items must be as per past client requests (Gimenez et al., 2012). To address client issues, MSMEs must have the option to improve every one of their exercises and methodologies. Gracefully Chain The executives (SCM) is a structure that upgrades all procedures did by an organization or association (Arzu Akyuz and Erman Erkan, 2010). SCM is an activity which covers every merchant development, after-deals administration which SCM realization can be the premise of upper hand to improve authoritative execution (Danese and Romano, 2011).

Collaboration in SCM can be assumed as an activity to improve organizational performance and can increase competitive advantage. To use supply chains that can improve performance, organizations must collaborate and combine the objectives and practices of their respective activities (Handfield et al., 2015). Different colleagues in the flexibly tie need to focus on specific segments to guarantee upper hand, cost exchanges to expand benefits, and money related cooperation endeavors to help inventive item plans (Kasiewicz, 2017). SCM is a type of combination and synchronization in accomplishing and is a response to changes in client request (Krmac, 2011). Past investigations have demonstrated that Gracefully Chain Incorporation (SCl) can affect hierarchical execution (Prajogo and Olhager, 2016). From past investigations it appears that another worth knowledge will be reflected in the effect of mix of gracefully chain techniques and practices on hierarchical execution, so this exploration investigates the impact of $\mathrm{SCl}$ on authoritative execution in Smaller scale, Little and Medium Ventures (MSMEs) in West Java.

Business strategies including SCM by large companies to increase growth have been substantially studied. Now, attention has shifted to differentiation strategies in MSMEs, which have less resources to produce and commercialize SCI (van de Vrande et al., 2009). One of the developing MSMEs in West Java is MSME fashion products. There are 207 SMEs of fashion products registered at www.diskumkm.jabarprov.go.id. West Java 
is one of the centers of fashion products that are quite well-known in the world of tourism (Wind, Ria and Balafif, 2017), therefore this study focuses on how Supply Chain Integration (SCI) conducted by MSME fashion products to improve performance in response to tourism development in West Java.

\section{LITERATURE REVIEW}

A wide range of writings on $\mathrm{SCl}$ and gracefully chain execution in different points of view, and every definition is adjusted to propensities, for example, research thoughts, business, and examination targets. SCl's understanding is about joint effort, cooperation and coordination among different partners in gracefully chain exercises, to improve hierarchical execution. Beneath this will be clarified in regards to $\mathrm{SCl}$ thoughts and gracefully chain execution, and associations with one another.

\section{Supply Chain Integration}

Supply Chain Integration ( $\mathrm{SCl}$ ) is defined as a collaborative procedure in supply chain activities that controls inter-organizational and intra-organizational activities to achieve efficient product, service and information flow to deliver the best value to customers in the right place at a right cost (Barney, 2012).

\section{Dimensions of Supply Chain Integration}

Dimensions of Supply Chain Management can be grouped into three that can be used in Supply Chain Integration (Maddeppungeng et al., 2015). Providers plan cautiously how data and necessities are required by colleagues, which at last providers have a critical job during the time spent getting ready items and administrations to address client issues (Nejadjavad and Gilaninia, 2016). Great and coordinated connections must be done by providers and clients to deal with contrasts in client request and diminish creation process durations and conveyance times dictated by the organization and clients (Huo, 2012). Providers right now, keep on assuming a job during the time spent item creation as a feature of the creation advancement process and to keep up the trust of clients (Handayani, 2016). Thusly, the examination portrays provider combination (SI) as a shared methodology among accomplices and associations that support the conveyance of information, experience, materials, and administrations. An incorporated information assortment that can divert the objectives of organizations, affiliations, and other extra issues that apply among providers and organizations (Todeva and Knoke, 2005).

Internal integration is the main point of attraction for suppliers and customers, and can be seen as a basis for maintaining stability and consistency for all parties in the supply change process so that a company cannot make a chain integration (CI) without Internal Integration (II ) (Xu et al., 2009). Establishing appropriate chain integration procedures, is very dependent on the existence of clear objectives and informed to all parts of the company, which can be obtained by receiving the right information to all functional divisions about the objectives of the company (Barney, 2012). Internal integration is determined as a way to maintain meaningful participation and cross-functional collaboration within the company, to achieve the company's strategic goals determined by a group of indicators that identify relationships, coordination and cooperation between every departments in the organization. The company must consider the customer as an important source for the company, so the company provides goods or services, which are seen as like the natural air needed by the organization to develop and as a form of capacity to survive in the face of extreme competition (BartosikPurgat \& Ratajczak- Mrożek, 2018). The needs and needs of customers are adjusted continuously to follow 
the desires of customers, so that it will be significant and complementary (Kasiewicz, 2017). Thus, companies must proactively observe the external environment but not reactively to be better than competitors to meet each customer's needs (Yu et al., 2013). $\mathrm{Cl}$ is made as a way to maintain and maintain stable relationships and partnerships with customers such as sharing information, services, outputs, and recommendations with and by customers, so that interrelated engagement and cooperation can be built (Todeva \& Knoke, 2005)

\section{Organizational Performance}

A broader and more efficient concept than a performance measurement must include operational performance indicators, as well as financial performance because they are non-financial measures that can overcome limitations where measures only use financial performance measures (Hervani et al., 2005). In theory, performance planning is a sub system of the performance management system, so that the objectives of performance planning are the same as those of performance management (Hendi, H. et al., 2019). Under dynamic environmental conditions, organizational reform activities as well as strategy reforms that can enhance a company's ability to innovate, take risks and be able to compete effectively are paramount (Fauzi, A. H., 2019). There are many advantages when using non-financial, measures including the fact that nonfinancial actions can provide a more appropriate time than financial actions. Financial performance measures will be increasingly scalable, and can be predicted with organizational goals and strategies (Silvi et al., 2015). Non-financial estimates change and vary after some time in light of the fact that the market needs to change because of these progressions can make the market adaptable (Gunasekaran, 2004). At the point when money related execution measures will undoubtedly reflect organization assessments by outside parts, operational advances show how simpler the viability of assignments inside the organization is (Podgórski, 2015). This exhibition grouping reflects ability in explicit regions of the flexibly chain, which incorporates costs, transportation speed and steady quality, unwavering quality and consumer loyalty. Authoritative execution measures give a sign of the flexibly chain measurement endeavors. Seeing the significance of money related and non-monetary execution, gracefully chain associations must join the two estimations (Huo, 2012)

\section{Conceptual Model}

Explanation of the above literature provides a $\mathrm{SCl}$ framework and company performance that can be developed. In the research that has been done, this reasonable model is adjusted and adjusted from Huo (2012) concentrate on the effect of $\mathrm{SCl}$ on organization execution: by utilizing the viewpoint of hierarchical or organization capacity.

\section{Figure 1. Conceptual Modification Model}

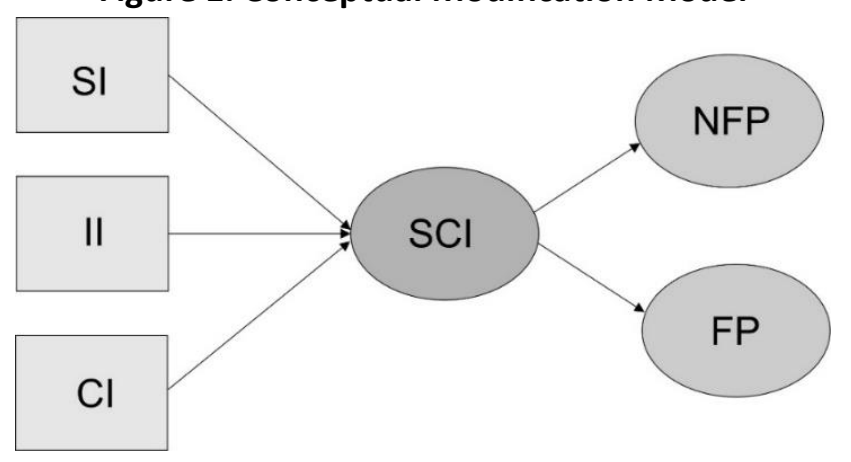

Source : Huo (2012) 


\section{RESEARCH METHODS}

The population of this research is MSMEs in fashion products in West Java province. Information about MSMEs is collected from www.diskumkm.jabarprov.go.id. Respondents targeted for the questionnaire were mainly UMKN owners who had sufficient knowledge about how their company carried out their supply chain functions and how effective their performance was.

This research is quantitative research. The independent variable in this study is Supply Chain Integration (SCI) and the dependent variable is organizational performance. This research uses survey method. To collect data, the questionnaire was sent to respondents selected as samples using randomly determined probability sampling. Furthermore, after the data is obtained then analysis and hypothesis testing are carried out and the results are empirical findings. Data analysis was performed using Structural Equation Modeling (SEM) using PLS. The population in this study is the fashion product MSMEs in West Java with a population of 207 MSMEs registered at www.diskumkm.jabarprov.go.id. The sample was determined by the Slovin formula and obtained a total sample of 135 respondents.

\section{RESULTS AND DISCUSSIONS}

The estimation model has the correct degree of legitimacy and unwavering quality before it can test the relationship of auxiliary models fundamentally (Asyraf and Afthanorhan, 2013). The psychometric properties of the estimation model were assessed by composite dependability (CR) and joined legitimacy (Hair et al., 1998). All develops display composite reliabiility with an adequate least degree of 0.60 , which shows the dependability of the build. The measures (Fornell and Larcker, 1981) and Storage's normal difference separated (AVE) are utilized to assess the legitimacy of joined scales. The AVE estimation of the idle variable must be higher than 0.50 , which is utilized in clarifying the greater part the fluctuation of the normal marker (Achjari, 2015). As represented in Table 1, all inactive development (flexibly chain joining) meets the measures.

Table 3. Validity and Reliability of the Research Scale

\begin{tabular}{|c|c|c|c|l|l|l|c|}
\hline Dimension & CR & AVE & MSV & \multicolumn{1}{|c|}{$\operatorname{MaxR}(\mathrm{H})$} & \multicolumn{1}{|c|}{1} & \multicolumn{1}{|c|}{2} & 3 \\
\hline $\mathrm{SI}$ & 0.913 & 0.513 & 0.068 & 0.922 & 0.717 & & \\
\hline $\mathrm{II}$ & 0.912 & 0.506 & 0.031 & 0.917 & $0.174^{*}$ & 0.712 & \\
\hline $\mathrm{Cl}$ & 0.922 & 0.542 & 0.068 & 0.935 & $0.263^{* *}$ & 0.073 & 0.736 \\
\hline
\end{tabular}

Source: Processed researchers (2018)

From table 3 , it tends to be reasoned that all composite unwavering quality (0.7) and merged legitimacy approaches Normal Fluctuation Separated qualities (0.5) for all develops are higher than ordinary levels. This backings the composite relaibility and concurrent legitimacy of a develop. Table 3 additionally shows that the Most extreme shared difference (MSV) is not exactly AVE, the greatest dependability (MaxR $(\mathrm{H})$ ) is more noteworthy than CR, AVE and the square foundation of AVE is more prominent than the between development connection that bolsters the discriminant legitimacy of the build (Achjari, 2015) 
Table 4. Standard Coefficient Table

\begin{tabular}{|c|c|c|}
\hline \multicolumn{2}{|c|}{ Structural Relationship } & Beta \\
\hline $\begin{array}{l}\text { Non-financial } \\
\text { Performance }\end{array}$ & \multirow{4}{*}{$\mathrm{SCl}$} & 0.647 \\
\hline FP & & 0.831 \\
\hline $\mathrm{Cl}$ & & 0.659 \\
\hline $\begin{array}{l}\text { Supplier } \\
\text { Integration }\end{array}$ & & 0.634 \\
\hline Lead Time & \multirow[b]{2}{*}{ Non-Financial Perfomance } & 0.464 \\
\hline $\begin{array}{l}\text { Customer } \\
\text { Satisfaction }\end{array}$ & & 0.554 \\
\hline Sales Growht & \multirow{2}{*}{ Financial Performance } & 0.415 \\
\hline Net Profit & & 0.452 \\
\hline
\end{tabular}

Source: Processed researchers (2018)

Table 4 shows the basic connection among $\mathrm{SCl}$ and money related execution, non-monetary execution of MSME design items in West Java territory. Generally $\mathrm{SCl}$ had fundamentally anticipated the three components of $\mathrm{SCl}$, among these three measurements, $\mathrm{SI}$ (beta $=0.805 ; \mathrm{p}<0.01$ ) was the most noteworthy indicator of II (beta $=0.659 ; \mathrm{p}<0.01$ ) and $\mathrm{Cl}$ (beta $=0.634 ; \mathrm{p}<0.01$ ). Consumer loyalty (beta $=0.554 ; \mathrm{p}<0.01$ ) is the most huge indicator of non-budgetary execution and net benefit (beta $=0.452 ; p<0.01$ ) is the most huge indicator of MSME money related execution in Java area West. gracefully chain coordination directly affects flexibly chain money related execution (beta $=0.831 ; \mathrm{p}<0.01$ ) and non-monetary execution (beta $=$ $0.647 ; p<0.01)$.

Table 5. Model Fit Statistics

\begin{tabular}{|c|c|c|c|c|c|c|c|}
\hline$X^{2}$ & Df & $X^{2 / d f}$ & GFI & AFGI & CFI & RMSEA & RMR \\
\hline 33.039 & 12 & 2.754 & 0.964 & 0.915 & 0.927 & 0.085 & 0.042 \\
\hline & - & $2-5$ & $>0.90$ & $>0.80$ & $>0.95$ & $<0.08$ & $<0.05$ \\
\hline
\end{tabular}

Source: Processed researchers (2018)

Model fit it can be measure by RMSEA (Achjari, 2015), which is under 0.08 has a decent match, and under 0.05 has a closer match. (Hu and Bentler, 1999) said that for the integrity of the fit model the GFI (Decency of Fit File) must be above 0.9. For a decent CFI fit model (Similar Fit List) must be more noteworthy than 0.9 (Hu and Bentler, 1999). As indicated by Hu and Bentler (1999) "Cutoff Models for Conformance Record in Examination of Covariance Structure: Ordinary Rules versus New Other options" and suggest a mix of activities. As per different models of factual appropriateness shows that the model is reasonable. 


\section{CONCLUSIONS}

The discoveries of this investigation give proof that $\mathrm{SCl}$ altogether impacts the presentation of MSME design items in West Java territory. This examination shows that the proprietors of MSME design items in West Java territory know about the Influence of $\mathrm{SCl}$ and its significance on budgetary execution and non-monetary execution. The autonomous factors (providers, interior, and clients) have a critical degree of combination. The scientists accept that $\mathrm{Sl}$ is a significant idea and incorporates acknowledgment of respondents about inward essentialness and $\mathrm{Cl}$ given the trouble in meeting client necessities to improve representative reactions and ways to deal with current culture. The outcomes can affirm that the gracefully chain system positively affects upper hand. Provider inclusion affects item development and makes a significant increment in organization returns. $\mathrm{Cl}$ builds the productivity of an organization's creation, $\mathrm{Cl}$ is a measuring instrument that is ranked second to measure $\mathrm{SCl}$. consumer loyalty is the primary objective that all organizations need to accomplish. At long last, II is the third degree of reconciliation since it is the substance among $\mathrm{SI}$ and $\mathrm{Cl}$, and it is hard to accomplish $\mathrm{SI}$ or $\mathrm{Cl}$ without II. These outcomes additionally show that $\mathrm{SI}$ has the most phenomenal effect on hierarchical execution, trailed by $\mathrm{Cl}$, most as of late II. These outcomes are in accordance with most past investigations, for instance, which show that there is a positive connection between $\mathrm{SCl}$ estimation and monetary and non-money related execution. Joining can be emphatically related to generally speaking hierarchical execution - for the most part through effects on efficiency, productivity and client assistance and fulfillment. Trust with clients/providers in a general sense impacts gracefully chain reconciliation Both $\mathrm{II}$ and $\mathrm{Cl}$ for all time improve monetary and non-budgetary execution. MSMEs that have high money related and non-budgetary execution can exploit the improvement of the travel industry in West Java to expand their salary. The expansion in pay for MSME style items in West Java is a reaction or answer to the difficulties of the travel industry improvement in West Java with the goal that they can turn out to be better and increasingly prosperous.

Organization should deliberately make an assortment of $\mathrm{SCl}$ capacities to accomplish different kinds of authoritative execution. For instance, associations should at first get ready II before they can accomplish outside joining. Besides, associations must concentrate on $\mathrm{Cl}$, which incorporates $\mathrm{CRM}$, clients as vital accomplices, share and impart on a progressing premise about item wanting to clients. This can fundamentally influence client situated execution. Consequently, in improving generally speaking execution, $\mathrm{Cl}$ is more powerful than gracefully incorporation. Associations must make gracefully chain joining, including strategic/vital direction with providers, share information with providers, cooperate with providers, plan coordinated effort with providers and provider relationship the board. An association needs to grow great connections, share data, and encourage structures between interior limit and with outside gracefully chain accomplices, to accomplish prevalent authoritative execution. At the point when rivalry has moved from the association to the flexibly chain, the association should purposefully make inward and outside integrative authoritative ability to address the issues of conditions, clients and accomplices. 


\section{REFERENCES}

Achjari, D. (2015). Partial Least Squares: Another Method of Structural Equation Modeling Analysis. Partial Least Squares: Another Method of Structural Equation Modeling Analysis, 19(3), 238-248. https://doi.org/10.22146/jieb.6599

Angin, Ria dan Balafif, B. (2017). Peran Jember Fashion Carnaval (JFC) Dalam Meningkatkan Pendapatan Asli Daerah (PAD) Kabupaten Jember (Sektor Pariwisata 2011-2015). Jurnal Komunikasi Universitas Muhammadiyah Jember.

Arzu Akyuz, G., \& Erman Erkan, T. (2010). Supply Chain Performance Measurement: A Literature Review. International Journal of Production Research, 48(17), 5137-5155. https://doi.org/10.1080/00207540903089536

Asyraf, W. M., \& Afthanorhan, B. W. (2013). A Comparison of Partial Least Square Structural Equation Modeling (PLS-SEM) And Covariance Based Structural Equation Modeling (CB-SEM) For Confirmatory Factor Analysis. International Journal of Engineering Science and Innovative Technology (IJESIT), 2(5), 198-205.

Badan Pusat Statistik. (2013). Gross Regional Domestic Product at 2000 Constant Market Prices by Provinces. Gross Regional Domestic Product at 2000 Constant Market Prices by Provinces. http://www.bps.go.id/linkTabelStatis/view/i d/1623

Barney, J. B. (2012). Purchasing , Supply Chain Management and Sustained Competitive ... Journal of Supply Chain Management, April, 3-6.

Danese, P., \& Romano, P. (2011). Supply chain integration and efficiency performance: A study on the interactions between customer and supplier integration. Supply Chain Management, 16(4), 220-230. https://doi.org/10.1108/13598541111139044

Fauzi, A. H., Rizal, M., \& Arifianti, R. (2019). Corporate Entrepreneurship in Smes : A Systematic Mapping Study. Jurnal Manajemen Pelayanan Publik, 2(1), 55. https://doi.org/10.24198/jmpp.v2i1.21575

Fornell, C., \& Larcker, D. F. (1981). Evaluating Structural Equation Models with Unobservable Variables and Measurement Error. Journal of Marketing Research, 18(1), 39. https://doi.org/10.2307/3151312

Gimenez, C., van der Vaart, T., \& van Donk, D. P. (2012). Supply Chain Integration and Performance: The Moderating Effect of Supply Complexity. In International Journal of Operations and Production Management (Vol. 32, Issue 5). https://doi.org/10.1108/01443571211226506

Gunasekaran, A. (2004). Editorial: Supply Chain Management - Theory And Applications. European Journal of Operational Research, 159(2 SPEC. ISS.), 265-268. https://doi.org/10.1016/j.ejor.2003.08.015

Hair Jr., J. F., Anderson, R. E., Tatham, R. L., \& Black, W. C. (1998). Multivariate Data Analysis (5th ed.). Prentice Hall.

Handayani, D. I. (2016). a Review: Potensi Risiko pada Supply Chain Risk Management. Spektrum Industri, 14(1), 25. https://doi.org/10.12928/si.v14i1.3701

Handfield, R. B., Cousins, P. D., Lawson, B., \& Petersen, K. J. (2015). How Can Supply Management Really Improve Performance? A Knowledge-Based Model of Alignment Capabilities. Journal of Supply Chain Management, 51(3), 3-17. https://doi.org/10.1111/jscm.12066

Hendi, H., Irawati, I., \& Candradewini, C. (2019). Perencanaan kinerja: Suatu studi tentang pengaruh sasaran kerja pegawai negeri sipil (Skp) terhadap kinerja pegawai pada badan daerah Di kabupaten merangin. Jurnal Manajemen Pelayanan Publik, 2(2), 87. https://doi.org/10.24198/jmpp.v2i2.20608 
Hervani, A. A., Helms, M. M., \& Sarkis, J. (2005). Performance Measurement for Green Supply Chain Management. Benchmarking, 12(4), 330-353. https://doi.org/10.1108/14635770510609015

Hu, L. T., \& Bentler, P. M. (1999). Cutoff Criteria for Fit Indexes in Covariance Structure Analysis: Conventional Criteria Versus New Alternatives. Structural Equation Modeling, 6(1), 1-55. https://doi.org/ 10.1080/10705519909540118

Huo, B. (2012). The Impact f Supply Chain Integration on Company Performance: An Organizational Capability Perspective. Supply Chain Management, 17(6), 596-610. https://doi.org/10.1108/13598541211269210

Kasiewicz, S. (2017). New Trends in the System Regulating the Market Of Bank Services. Kwartalnik Nauk O Przedsiębiorstwie, 45(4), 7-21. https://doi.org/10.5604/01.3001.0010.7450

Krmac, E. (2011). Intelligent Value Chain Networks: Business Intelligence and Other ICT Tools and Technologies in Supply/Demand Chains. Supply Chain Management - New Perspectives, March, 581614. https://doi.org/10.5772/18850

Maddeppungeng, A., Abdullah, R., \& Kaswan. (2015). Analisis Integrasi Supply Chain Management ( SCM ) Terhadap Kinerja Dan Daya Saing Pada Industri Kontruksi. Jurnal Fondasi, 4(2), 19-30.

Nejadjavad, M., \& Gilaninia, S. (2016). The Role of Service Quality in Organizations. Kuwait Chapter of Arabian Journal of Business and Management Review, 5(7), 19-27. https://doi.org/10.12816/0019403

Podgórski, D. (2015). Measuring Operational Performance of OSH Management System - A Demonstration of AHP-Based Selection of Leading Key Performance Indicators. Safety Science, 73, 146-166. https://doi.org/10.1016/j.ssci.2014.11.018

Prajogo, D. I., \& Olhager, A. O. J. (2016). Supply chain processes: Linking supply logistics integration, supply performance, lean processes and competitive performance. International Journal of Operations \& Production Management, 36(2), 1-5.

Prasetyo, B., \& Suryoko, S. (2018). Dampak Pengembangan Pariwisata terhadap Perkembangan UMKM pada Kawasan Wisata Dieng. Journal Of Social And POlitic, 1-11.

Silvi, R., Bartolini, M., Raffoni, A., \& Visani, F. (2015). The Practice of Strategic Performance Measurement Systems: Models, Drivers And Information Effectiveness. International Journal of Productivity and Performance Management, 64(2), 194-227.

Todeva, E., \& Knoke, D. (2005). Strategic Alliances and Models of Collaboration. Management Decision, 43(1), 123-148. https://doi.org/10.1108/00251740510572533

van de Vrande, V., de Jong, J. P. J., Vanhaverbeke, W., \& de Rochemont, M. (2009). Open innovation in SMEs: Trends, motives and management challenges. Technovation, 29(6-7), 423-437. https://doi.org/ 10.1016/j.technovation.2008.10.001

Xu, H., Koh, L., \& Parker, D. (2009). Business Processes Inter-Operation For Supply Network Co-Ordination. International Journal of Production Economics, 122(1), 188-199. https://doi.org/10.1016/ j.ijpe.2009.05.015

Yu, W., Jacobs, M. A., Salisbury, W. D., \& Enns, H. (2013). The Effects of Supply Chain Integration on Customer Satisfaction And Financial Performance: An Organizational Learning Perspective. International Journal of Production Economics, 146(1), 346-358. https://doi.org/10.1016/j.ijpe.2013.07.023 